\title{
A Brief Discussion on Motivation and Ways to Motivate Students
}

$$
\text { in English Language Learning }
$$

\author{
Yuan Kong \\ Foreign Language Stafff Room, Jining Medical College \\ Rizhao University City, Shandong 276826, China \\ E-mail: kongy_1116@163.com
}

\begin{abstract}
With the requirement of economic development, English has become more and more important that people begin to learn English with fully enthusiasm even from younger age. Learning a foreign language is not a simple and easy job but sometimes it is boring and dull. Motivation is critical in English learning, thus, how to effectively motivate students in English learning is an important problem. This paper expounds this importance and ways to motivate students. First, the author shows the definition of motivation and then explains intrinsic and extrinsic motivation and their relations, following with some personal factors that influence motivation. At last, according to the rationale, the author suggests several effective ways to motivate students in English learning.
\end{abstract}

Keywords: Motivation, English language learning, Ways

\section{Introduction}

In recent years in China, learning English has been a very prevalent tendency and it has become more popular and urgent as China succeeded in bidding to hold the 2008 Olympic Games and entering into the World Trade Organization. Mastery of a foreign language, especially English is viewed as a passport to one's future success, thus, more and more people swarm into the tide of English learning. In addition, the English learners have become younger and younger that English courses are taught in Grade Three or Grade One of primary schools and even in kindergartens. Furthermore, most of parents send the children to some after-school English classes on the weekends in the hope of promoting the children's English learning, yet some of the teachers and parents are in frustration of recognition of the children's low attitude and grades in English learning. Therefore, as teachers should know the psychological theory and the process of English learning in order to encourage and enhance the English learning of students.

Language learning is a very complicated process that is influenced by many factors. Besides the intelligent factor, the non-intelligent factors----motivation, attitude, interests, age, methods, will and character----are the direct and the most important factors to English learning. Because the behavior of English learners is dominated by cognition, in other words, the learners have a desire in which is a drive to persist in English learning. It is true that two students sit next to each other in a class. They look alike and are similar in ability, but they act very differently. One jumps into assignments, participates eagerly in class, and gets good grades; the other hesitates on assignments, seldom joins in discussion, and barely gets by. Why? This situation is typical. How many times have we heard teachers say," She could. " Theories of motivation help us explain these differences. In Jakobovits's research, he shows that the mainly influential factors to English learning are: motivation which takes up 33\%, aptitude which takes up 33\%, intelligent which takes up 20\%, and others which take up 14\%(cited in Jia Guanjie, 1996). Therefore, teachers and parents are interested in motivation, which can drive students in English learning actively.

\section{Theoretical Rationale}

\subsection{Definition of motivation}

\subsubsection{In the term of psychology}

People are always motivated; in fact, they are never unmotivated. They may not be motivated to do what we would prefer they do, but it can never be truly said they are unmotivated (Belyayev, 1963). In psychology, motivation is a force that energizes and directs behavior toward a goal (Paul Eggen \& Don Kauchak, 1994). Just as a force moves an object, motivation moves a person. More visualized, if individuals are machines, motivation is as the very engine that powers and directs individuals' behavior. Motives serve three important functions: 1) energizing us (i.e., turning the key and starting the motivational engine), 2) directing us (i.e., pointing us in a particular direction), and 3) helping us to select the behavior most appropriate for achieving our goals (Don Hamachek, 1989, p.262). In a word, motivation is an inner 
state that arouses individual's desire for a goal and maintains their efforts in a certain direction and time.

\subsubsection{In language learning}

Motivation is not only an intensive desire for learning and acquiring knowledge of English, but also an inner cause that push students forward in English learning with enthusiasm and willingness. It is something like the engine and steering wheel of an automobile that can moves students from boredom to interest. It is an inner power to drive and persevere students in English learning. Gardner indicates that the motivation of foreign language learning contains four aspects: a goal, effortful behavior, a desire to attain the goal and attitude (cited in Jia Guanjie, 1996). Students who have strong learning motivation take a correct and positive attitude towards study and make great efforts to master English with clear goal and desire and consequently gain better grade than those who haven't acquired motivation and those students usually regard English learning as a heavy and boring burden. It is true that motivation is such a basic factor in language learning that no teacher could avoid being concerned with students' motivation. So it is necessary to understand motivation more deeply, an idea the author turns to next.

\subsection{Intrinsic and extrinsic motivation}

Motivation can be described in many types and the main broad categories are intrinsic and extrinsic motivation.

\subsubsection{Definition of intrinsic motivation}

Intrinsic motivation is a response to needs that exist within the learner, such as curiosity, the need to know, and feelings of competence or growth (Paul Eggen \& Don Kauchak, 1994, P.428). It exists when someone works because of an inner desire to accomplish a task successfully, whether it has some external value or not (Cheryl L. Spaulding, 1992, p.4). In other word, students are willing to learn the knowledge that is new and interesting in the purpose of fulfilling of their curiosity, the need to know and feeling of competence and growth that cause intrinsic motivation. Their purpose of learning is also the enjoyment of the learning process not for praise or rewards. Students with intrinsic motivation orientation study English on their own initiative and tend to prefer moderately challenging tasks. This has a great value and importance in learning, for the inward interest makes them self-starting and self-perpetuating and can keep the motivational machinery going for a long time.

\subsubsection{Definition of extrinsic motivation}

In contrast, extrinsic motivation is as an outward force in the form of expectation, praise and rewards powers students in English learning. It exists when individuals are motivated by an outcome that is external or functionally unrelated to the activity in which they are engaged (Cheryl L. Spaulding, 1992, p.4). When students work hard to win their parents' favor, gain teachers' praise, or earn rewards such as pocket money, we can rightly conclude that their motivation is primarily extrinsic, their reason for work and study lie primarily outside themselves and the aim of learning is not for the knowledge itself but the outward rewards in order to gain self-esteem. And the outward praise and rewards encourage students to study more actively.

\subsubsection{Relationship between intrinsic and extrinsic motivation}

Both intrinsic and extrinsic motivations are important, inseparable and complementary to each other in English learning. Intrinsic motivation is the type of inner drive that propels students forward and onward with continuous energy fueled by its own curiosity and interest. However, in the real world not all of the students are automatically energized to perform this or that task, or to learn about this or that topic. Sometimes, a good grade, the threat of failing and praise move students from an inactive to an active state. The use of rewards as extrinsic motivators have sometimes been found to increase intrinsic motivation, especially when the rewards are contingent on the quality of the performance rather than simply on participation. It is clear that extrinsic motivators are sometimes necessary either to get students started in the first place, or to start them down a track that they might not know exists (Don Hamachek, 1989, p.267). However, overstressing the use of extrinsic motivation can stifle intrinsic motivation.

\subsection{Personal factors in motivation}

Motivation can be explained as interactions among behavior, the environment, cognitions, and personal factors. And personal factors take a very important position in individual English learning. Here, let's focus on these four personal factors: arousal, needs, beliefs, and goals.

\subsubsection{Motivation and arousal}

Paul Eggen and Don Kauchak (1994) explains:

Arousal is a physical and psychological reaction to the environment, including anxiety and curiosity motivation. Anxiety is arousal to the point of general uneasiness and tension and curiosity motivation is based on the idea that students derive pleasure from activities with an optimal (intermediate) level of surprise, discrepancy, or incongruity - each of which induces arousal.

When a teacher hands out a test, the students are sitting nervously and curious about the content of the test, with 
elevated blood pressure, fast breath and sweaty hands. This time, the students are alert and wide-awake. They are aroused and their motivation is at a high level. An optimum level of arousal is needed for peak performance. So an appropriate arousal assists in enhancing motivation.

\subsubsection{Motivation and need}

A need is the lacking of something necessary or desirable. In Maslow's hierarchy of needs, he divided needs into two categories. The bottoms four are called deficiency needs, and the top three are called growth needs. Until the lower needs are met, people are likely to move to higher ones. His work has important implications for education. In classroom, students who are threatened by potential embarrassment are less motivated to learn, until they study in secure and relaxed environment, they will move to the need for competence which related to competence motivation that is an innate need in human beings that energizes people to master tasks and skills. The need for achievement drives students to fulfill their goals. Students with a high need for achievement tend to be motivated by challenging assignments, high grading standards, explicit feedback, and the opportunity to try again. In contrast, students with a need to avoid failure avoid challenging tasks and experience anxiety in testing situation. Being aware of these differences can help teachers respond different students with different needs and as a result, teach all students more effectively.

\subsubsection{Motivation and beliefs}

A third personal factor that affects people's motivation is their beliefs. An optimistic belief about one's ability in English learning can help students increase their motivation. In incremental view of the beliefs about ability, human can hold the beliefs that ability can be improved with effort. Although students incline to be influenced by teachers' evaluation of their ability in participating activities, they have an optimistic view of their ability to a certain extend which cause their self-confident originally. They also react strongly to failure and self-doubt. A linking theory is attribution theory, which is an attempt to systematically describe students' explanations for their successes and failures in classroom situations. So teachers can help students attribute their successes o ability and effort while failure bad luck and task difficulty and provide them more opportunities to experience success for the sake of setting an optimal belief of the learning ability as well as enhancing learning motivation.

\subsubsection{Motivation and goals}

Students' goals influence their motivation and effort in English learning. With learning goal, students study purposefully and throw great effort into English learning. They are concerned about mastering of language and accomplishing tasks and not worried about failure or comparison to others. It is effective to help students setting realistic and appropriate goals in motivating them in learning.

\section{Ways to motivate students in English learning}

"You can lead a horse to water, but you can't make him drink." Motivating students is a little like that. It involves not only leading them to English, but also making them thirsty for knowledge and understanding of English. As a language learning, English learning has its own characteristics that need the learners remember more, practice more and communicate more than other subjects. Students' motivation is critical for English learning. English teachers are organizers or leaders in teaching. They have responsibility to increase their students' inclination to perform willingly and actively on English learning.

\subsection{Using various and interesting activities}

It is effective and functional to apply various and interesting activities with moderate challenge to attract students to arouse their curiosity in English learning in view of intrinsic motivation, arousal and the characteristic of language learning. Language learning is a little different from other subjects that need students to develop roundly in four skills of listening, speaking, reading and writing by remembering plenty of vocabulary, sentences and grammar, practicing and speaking more in class. Students are willing to participate in English learning by Combining English with recreation and to realize that English learning can be interesting and fun with their involvement in which is the key to maintaining motivation throughout a lesson. Games are welcomed in English teaching especially in elementary schools. As Aydan Ersoz explains:

Well-chosen games are invaluable as they give students a break and at the same time allow students to practice language skill. Games are highly motivating since they are amusing and at the same time challenging. Furthermore, they employ meaningful and useful language in real contexts. They also encourage and increase cooperation

Guessing game, gap filling, chain story games are practical and interesting that can be used in English learning. In-role play, songs and summer English camping trips are also effective. Some real situation discussion and creative activities such as create an advertisement are encouraged in higher grade. Various and interesting activities encourage students involve as much of the time and effort as possible and as well as enhance learning motivation. 


\subsection{Involving new and effective techniques}

As some techniques have been employed in teaching, there are more choices and more methods for teachers to stimulate students' intrinsic motivation such as CALL (computer assisted language learning), multimedia, using Internet and educational software. These methods are innovative, interesting, practical and effective with colorful pictures, vivid voices, plentiful information and effective interaction that arouse students' curiosity and interest and as well as promote their intrinsic motivation. With intrinsic motivation, many students can start self-study in schools or at homes to effectively improve their listening, reading and writing through this method.

\subsection{High expectation and using reward appropriately}

High expectation and using reward appropriately are effective methods as outward power to stimulate students in English learning on the basis of extrinsic motivation theory. Sometimes our expectations about people cause us to treat them in ways that make them respond just as we expected they would (David Freeman \& Yvome, S. Freeman, 1978). Extrinsic - motivated students need to be refueled by outward energy such as teachers' high expectations, praise and some rewards. Research demonstrates that teacher expectations influence student achievement----higher expectation can yield better performance from students. "I know that you can all solve these problems if you work at it. Now get started and I'll help you if you run into some problems." These words show the teacher's emotional support and confidence in the student's abilities and as result the student who is especially introversive and shy to speak in class tries his or her best to overcome the problems with expectation. Moreover, during class, teachers can ask students to answer questions more often, which are more complete and accurate, and allow more time to answer and give more encouragement to stir up their arousal. And after exams, cooperative activities and home assignments, teachers can offer more complete and positive feedback or evaluations to students about their performance. Meanwhile, as teachers, do not forget to give more effective and appropriate rewards, which must be explained why the student deserves it; avoid giving severe criticism which will lower student motivation and rewards excessively that students may rely on rewards as the reason for learning not for the knowledge itself

\subsection{Create a relaxed and positive learning climate}

Climate is important because it creates an environment that encourages both achievement and motivation (Richards, J. C., \& Theodore, S. R., 1988). From the view of Maslow's hierarchy theory, motivation and need and the character of English learning, a relaxed and positive learning climate should be providing for students learning English. In a friendly atmosphere, students can feel secure and their sense of understanding and challenge as well as learning motivation can be promoted. In English learning, students need a great deal of practice to speak in class, thus implementing some rules to ensure them make sufficient use of the practice time and at the same time to make them feel safe and comfortable and are away from criticism and laughing by making mistakes. Meanwhile, teachers should allow students to discuss broadly without the fear of expressing their own thoughts different from others. When students make some mistakes, teachers describe them as opportunities for improvement with warm comments, such as" This is a good experience for you. When you finally get it, you will have improved a lot." with more smiles and encourages, teachers can have more interactions and stand closer to students. Afterward, before starting class and activity, teachers' explanation of what students supposed to be learning and why they are learning it promote a sense of value and make students more clear and positive in learning English. Then teachers should present tasks with challenging in the principle of neither too easy nor too difficult that beyond the students' capacity, because tasks that are too difficult discourage them from trying; tasks that are too easy produce boredom and decreased feelings of competence and self-efficacy (Hu Chundiao, 1990, p.460). And when students are dealing with the tasks, teachers should prepare to give supportive aids at any moment.

\subsection{Cooperative activities}

Cooperative activities are at optimal level to keep students feel safe and can stimulate their arousal. Thus, more and more teachers use cooperative activities in English teaching rather than competition, which is also relatively effective. In cooperative activities, students can decrease fear of failure while communicate and exchange information effectively and involve with high emotion and efforts to solve problems. In this case, students who are reluctant and fearful to perform are drawn to participate to share their ideas. This method is suitable for higher level of students to communicate in English. For example, group discussing and doing project, which are complex and challenging, are a good way to enable students to work cooperatively with peers. And as teachers, it is more effective to provide helps and comment fairly on their work in time or ask students to make a self-evaluation about their projects. This enables students to focus on their learning process and allows them to see their progress. And self-evaluation gives students a sense of accomplishment and responsibility for learning.

\subsection{Providing opportunities for students to experience success}

The most important use of learning English is to communicate with people by using the target language, but not all of the learners are active to use English especially when they frustrated by failure in English learning. The more ways we can give our students to use English, have fun with English and experience success in English learning, the more likely 
we are to keep all our students motivated and successful based on the theory of needs and beliefs. And Hamachek has done a good deal of research on the effects of failure on school achievement, and almost without exception concluded that success tends to encourage students to raise their level of aspiration, whereas failure generally causes them to lower it (1972). This point can be reached by providing more chances to join activities for students to experience success with more freedom and self-determination. For instance, teachers can take five minutes out of every class time for students to do the "I am a teacher today" activity in which provides students an opportunity to change their role into teacher to teach other students English on class as a sense of success. During these five minutes, students can decide what to teach such as to review, to teach new words and to tell story.

\section{Conclusion}

In conclusion, motivation is fatal important and the ways to motivate students in English learning is more important to English learning. The ways the author mentioned above are relatively effective to motivate and sustain students in English learning. Sometimes, teacher is rather like a salesman who must convince and persuade his consumers (i.e. students) to believe that he has what they need and what is useful for them (cited in Kripa, 1988). As a teacher, it is essential and useful to acquire more knowledge of educational psychology especially motivational rationale and effective methodologies and meanwhile come up with the new techniques to be a good "salesman" to motivate and sustain students in English learning.

\section{References}

Belyayev, B. V. (1963). The psychology of Teaching Foreign Languages. Oxford: Pergamon Press.

Brook, N. (1964). Language and Language Learning. New York: Harcourt, Brace and world.

Cheryl L. Spaulding. (1992). Motivation in the classroom. The United States: McGraw-Hill.

David Freeman \& Yvome, S. Freeman. (1978). A Road to Success for Language. New York: Oxford University Press.

Don Hamachek. (1989). Psychology in teaching, learning, and growth. The United States: Allyn and bacon.

Gao Yihong. (2001). Foreign Language Learning: " $1+1>2$ ”. Beijing: Beijing University Press.

Gu Xueliang. (1998). The Basic Technical Training in English Teaching. Zhejiang: Hangzhou University Press.

Gui Shichun. (1991). An outline of Experimental Psycholinguistics. Hunan: Hunan Educational Press.

He Guangkeng. (1999). The Basis of English Teaching and Learning Methods. Jinan: Jinan University Press.

Hu Chundiao. (1990). The English Teaching and Learning Methods. Beijing: Higher Education Press.

Jia Guanjie. (1996). Psychology of foreign languages education. Guangxi: Guangxi Education Press.

Kripa, K. Gautam. (1988). English language teaching: a critical study of methods and approaches. New Delhi: Harman.

Larsen, Freeman \& Diane. (2000). Techniques and Principles in Language Teaching. (2nd ed.). Oxford University Press.

Li Shunying. (1999). On the Effectiveness of Teacher Talk in the ELT Classroom. Teaching English in China. Issue 36. December. 1999. Bejing: Foreign Language Teaching and Research Press.

M. A. K. Halliday et al. (1964). The Linguistic Sciences and Language Teaching. London: Longman.

Paul, D. Eggen, \& Don Kauchak. (1994). Educational psychology: classroom connections. The United States: Macmillan.

Richards, J. C. \& Theodore, S. R. (1988). Approaches and Methods in Language Teaching. New York: Cambridge University Press.

Saul Kassin. (1998). Psychology. The United States: Prentice-Hall.

Smith, F. (1978). Understanding Reading. (2nd ed.). New York: Holt, Rinehart and Winston.

Van, E. K., J. A. \& Alexander, L. G. (1980). Threshold Level English. New York: Oxford University Press.

Wang Duqin. (2002). On Strategies of English Teaching. Foreign Language Teaching and Research Press.

Widdowson, H. C. (1979). The communicative Approach and its Applications. Oxford University Press.

Wilga, M. Rivers, \& Mary, S. Temperley. (1978). A practical guide to the teaching of English as a second or foreign Language. New York: Oxford University Press. 